\title{
PROFIL RESILIENSI PENDIDIK BERDASARKAN RESILIENCE QUETIENT TEST
}

\author{
Pribastuti \\ Fakultas Psikologi UNAIR \\ Jl. Airlangga 4-6 Surabaya 60286 \\ prihastuti@unair.ac.id
}

\begin{abstract}
Abstrak
Penelitian ini bertujuan untuk memperoleh gambaran umum profile resiliensi pendidik Fakultas Psikologi Unair melalui Resilience Quotient Test (RQ). Instrumen yang digunakan adalah Resilience Quotient Test, yang terdiri 56 item. Resilience Quotient Test memuat 7 faktor, yaitu: emotional regulation, impulse control, emphati, optimism, causal analysis, self-efficacy dan reaching-out. Analisis profile resiliensi dilakukan berdasarkan perbandingan nilai rata-rata dari masing-masing faktor dengan nilai acuan yang sudah ditentukan dalam Resilience Quotient Test. Hasil penelitian menunjukkan 2 faktor berada pada kategori di atas rata-rata (impulse control dan optimism), 3 faktor berada pada kategori rata-rata (empathy, causal analysis dan reaching-out) dan 2 faktor berada pada kategori di bawah rata-rata (emotional regulation dan self-efficacy). Dua faktor yang berada pada kategori di atas rata-rata, yaitu impulse control dan optimism belum menunjukkan hasil yang mantap karena tidak didukung oleh faktor lainnya yang berada pada system belief yang sama, yaitu emotional regulation dan selfefficacy. Oleh karena itu, impulse control yang berlawanan dengan emotional regulation serta optimism yang berlawanan dengan self-efficacy perlu dikaji lebih dalam.
\end{abstract}

Kata kunci : profile resiliensi pendidik 


\title{
EDUCATORS' RESILIENCE PROFILE BASED ON THE RESILIENCE QUOTIENT TEST
}

\author{
Pribastuti \\ Faculty of Psychology UNAIR \\ Jl. Airlangga 4-6 Surabaya 60286 \\ prihastuti@unair.ac.id
}

\begin{abstract}
This research aims to obtain an overview of profile resilience educators of the Faculty of Psychology Unair through the Resilience Quotient Test (RQ). The instrument used was the Resilience Quotient Test, which comprised 56 items. The test of the Resilience Quotient included seven factors, namely emotional regulation, impulse control, empathy, optimism, causal analysis, self-efficacy and Reaching-out. The analysis of profile resilience was based on comparison of the average value of each factor with a predetermined reference value in the Resilience Quotient Test. The results show that two categories of factors are above average (impulse control and optimism), 3 factors are in the average category (empathy, causal analysis and Reaching-out) and the second factor is in the category below the average (emotional regulation and self-efficacy). Two factors that are on the above average categories, namely impulse control and optimism, have not been steady because they are not supported by other factors that are on the same belief system, namely emotional regulation and self-efficacy. Therefore, impulse control as opposed to emotional regulation and optimism as opposed to self-efficacy needs to be studied more deeply.
\end{abstract}

Keywords: profile resilience educators 


\section{Pendahuluan}

Resiliensi sebagai suatu fenomena pada awalnya muncul karena ketidaksengajaan dari suatu riset untuk menemukan faktor-faktor resiko yang menyebabkan kondisi psikopatologis pada anak-anak. Riset yang pada awalnya untuk mengidentifikasi kerusakan yang dialami anak-anak dan mencari penanganan yang tepat untuk menolong mereka dalam menghadapi resiko kehidupan justru menemukan bahwa sepertiga dari anak-anak yang hidup dengan resiko kehidupan tersebut ternyata memiliki kemampuan untuk beradaptasi dengan berbagai permasalahan yang mereka hadapi (Werner \& Smith, 1982; Garmezy, 1985). Fenomena ini memunculkan perkembangan paradigma baru tentang identifikasi dini anak-anak yang hidup dalam faktor resiko yaitu prediksi terhadap faktor-faktor resiliensi, yaitu kekuatan yang dapat melindungi anak-anak yang memiliki resiko tinggi terhadap penyimpangan perkembangan, bukannya terjebak pada model patologis dalam melihat perkembangan anak (Frakenburg, 1987).

Kemunculan fenomena resiliensi tersebut menimbulkan penyadaran bagi kalangan para peneliti untuk melakukan perubahan paradigma dalam dunia penelitian psikologi, yang awalnya difokuskan untuk melihat efek negatif dari berbagai keadaan yang menyebabkan kondisi patologis, kini diarahkan untuk melihat sisi positif dari sebuah situasi yang dapat menyebabkan seseorang memiliki daya tahan terhadap berbagai kondisi yang kurang menguntungkan. Perkembangan paradigma ini kemudian mengarah pada usaha pendefinisian resiliensi, yang ternyata terdapat banyak perbedaan terhadap konsep tentang apa yang dimaksud dengan resiliensi, karakteristik serta dinamikanya (Gordon, 1994). Berbagai usaha tersebut dilakukan untuk mendapatkan gambaran yang komprehensif tentang apa dan bagaimana seseorang berproses untuk mencapai kualitas resiliensi.

Satu definisi yang umum digunakan, termasuk juga dalam Proyek Resiliensi Internasional menyebutkan bahwa resiliensi adalah kapasitas universal yang membuat seseorang ataupun sebuah komunitas mampu meminimalkan atau menghindari efek yang negatif dari peristiwa-peristiwa 
yang menyedihkan/menyakitkan. Dengan kata lain, secara umum resiliensi merupakan suatu kemampuan yang dimiliki oleh seseorang atau suatu komunitas yang memungkinkannya mampu untuk menghadapi dan mengatasi permasalahan. Jika seseorang atau komunitas menghadapi permasalahan, sebenarnya ia memiliki kekuatan untuk mengatasinya, berupa keberanian, keterampilan atau keyakinan. Semua ini dilakukan sebagai cara untuk dapat menyesuaikan diri dengan situasi yang tengah dihadapinya dan sebagai usaha untuk tetap bertahan hidup. Kekuatan semacam inilah yang dikenal dengan istilah resiliensi. Istilah resiliensi terkait erat dengan istilah ego resiliensi yang pertama kali disampaikan oleh Block dalam Klohnen (1996). Ego resiliensi menurut Cohn, dkk (2009) disebut sebagai bentuk kepribadian yang stabil, mencerminkan kemampuan individu untuk menyesuaikan diri dengan lingkungannya. Respon adaptif ini dapat meliputi kemampuan mengidentifikasikan kesempatan, menghadapi berbagai kendala, serta keluar dari kondisi yang tidak menguntungkan. Luthar, dkk (2000) mendefinisikan resiliensi sebagai proses dinamis yang mengarah pada kemampuan yang positif untuk menyesuaikan diri dalam situasi yang sulit, sedangkan Tugade dan Fredickson (2004) mengidentifikasi sebagai kemampuan untuk cepat beralih dari pengalaman emosi negatif dan kemampuan beradaptasi dalam menanggapi suatu pengalaman yang penuh dengan tekanan. Oleh karena itu, resiliensi dapat dipahami sebagai kemampuan setiap orang untuk meminimalkan atau mengatasi tantangan yang dirasakan yang dapat mengganggu penyesuaiannya. Berkat dimilikinya resiliensi seseorang akan dapat mencegah dan meminimalkan dampak buruk dari peristiwa-peristiwa negatif dalam hidupnya. Bahkan, adakalanya peristiwa atau kesulitan hidup yang dihadapi itu justru akan memperkuat ketahanan mentalnya (Grotberg, 1999).

Hasil beberapa penelitian telah menunjukkan secara meyakinkan bahwa resiliensi merupakan kunci kesuksesan dan kepuasan hidup. Selama puluhan tahun Benard telah mengumpulkan hasil penelitian tentang resiliensi yang menunjukkan bahwa peran keluarga, sekolah dan masyarakat menjadi kunci pengelolaan dorongan-dorongan biologis seseorang untuk mencapai perkembangan yang normal ("Resilience: What We Have Learned"). 
Resiliensi sebagai kemampuan untuk tetap bertahan \& menyesuaikan kon-disi atau situasi pada saat menghadapi problem perlu diketahui, dipertahan-kan dan ditingkatkan oleh setiap orang. Orang yang resiliensinya tinggi tahu bagaimana ia harus menghadapi suatu masalah dan dapat menemukan cara penyelesaiannya. Mereka tetap berkembang meskipun lingkungan berubah terus-menerus, karena mereka fleksibel, cerdas, kreatif, cepat beradaptasi serta belajar dari pengalaman ('The Resiliency Center). Meskipun sebagai konsep yang abstrak, resiliensi secara genetik bukanlah kapasitas yang merupakan "fixed trait", oleh karena itu bisa diajarkan dan ditingkatkan. Diingatkan oleh Rutter (1987) dalam artikelnya bahwa "resiliensi tidak dapat dilihat sebagai atribut tetap dari diri seseorang, ketika situasi berubah, kualitas resiliensi pun terpengaruh"

Berbagai penelitian menekankan bahwa resiliensi dapat dipupuk melalui berbagai teknik, misalnya penggunaan humor, teknik-teknik relaksasi, dan cara berpikir positif. Reivich dan Shatte melalui penelitan mengenai pelatihan keterampilan untuk meningkatkan resiliensi telah menemukan bahwa individu yang terlibat dalam pelatihan tersebut merasa lebih kuat, percaya diri, merasa nyaman untuk berhubungan dengan orang lain, bersemangat dalam menemukan pengalaman-pengalaman baru, serta lebih berani mengambil resiko.

Reivich dan Shatte (2002) menjelaskan bahwa resiliensi memiliki empat fungsi dasar dalam kehidupan manusia, yaitu :

(1) mengatasi kesulitan-kesulitan yang pernah dialami di masa kecil. Beberapa orang mengalami pengalaman pahit di masa kecil, misalnya kemiskinan, kekerasan, atau broken bome, resiliensi bermanfaat untuk meninggalkan akibat buruk dari pengalaman-pengalaman pahit tersebut dengan lebih memusatkan pada tanggung jawab pribadi untuk mewujudkan masa dewasa yang diinginkan;

(2) melewati kesulitan-kesulitan dalam kehidupan sehari-hari, misalnya menghadapi konflik dengan rekan atau keluarga dan menghadapi kejadian yang tidak diinginkan. Seseorang dengan resiliensi yang baik tidak akan membiarkan kesulitan yang dihadapinya sehari-hari mempengaruhi produktivitas atau kesejahteraannya; 
(3) bangkit kembali setelah mengalami kejadian traumatik atau kesulitan besar. Menghadapi situasi krisis dalam hidup seperti kematian, perpisahan akan menyebabkan ketidakberdayaan seseorang. Kemampuan untuk segera bangkit dari ketidakberdayaan tersebut akan tergantung dari tingkat resiliensi seseorang;

(4) mencapai prestasi terbaik. Resiliensi dapat membantu untuk mengoptimalkan segala potensi diri untuk mencapai seluruh cita-cita dalam hidup. Mencapai tujuan hidup dengan bersikap terbuka terhadap berbagai pengalaman dan kesempatan.

Kunci kesuksesan resiliensi adalah kemampuan untuk mengenali pikiran dan struktur kepercayaan serta memanfaatkan kekuatan untuk meningkatkan akurasi serta fleksibilitas berpikir untuk mengatur emosi dan perilaku yang lebih efektif. Kemampuan ini dapat diukur, diajarkan, dan diperbaiki (Jackson \& Watkin, 2004). Oleh karena itu, pada dasarnya resiliensi tidak ditentukan oleh seberapa banyak kesulitan yang telah dilewati sebagai penentu keberhasilan atau kegagalan dalam menghadapi keadaan yang sulit, namun lebih ditentukan oleh (1) tingkat akurasi dalam mempertimbangkan suatu keadaan sulit; (2) banyaknya alternatif skenario yang dapat dibayangkan; (3) kemampuan untuk bersikap fleksibel dan; (4) melanjutkan hidup untuk meraih kesempatan baru.

Dalam perkembangannya resiliensi juga memiliki peranan penting di dunia pendidikan. Tidaklah realistik untuk mengharapkan peserta didik yang resiliens jika para pendidiknya tidak resiliens. Jika para pendidik itu sendiri berada dalam situasi yang beresiko tinggi \& tak mampu mengatasi, bagaimana mereka dapat menemukan energi dan kekuatan untuk meningkatkan resiliensi di kalangan peserta didik. Bagaimana peserta didik bisa diharapkan untuk menghadapi tantangan dengan peilaku dan sikap yang lebih resiliens, jika para pendidik sebagai role model tidak menunjukkan sifatsifat tersebut. Pendidik adalah salah satu kelompok penting yang mendorong resiliensi peserta didik, dengan demikian mereka harus menunjukkan resiliensi dalam diri mereka, meskipun kondisi di mana mereka bekerja dapat membuat ini sulit. Rasa well-being \& efektivitas pendidik tertantang oleh tiga faktor lingkungan, yaitu: 
(1) perubahan harapan-harapan terkait dengan apa yang harus dilakukan sekolah dan bagaimana mereka harus melakukannya. Bergesernya ke arah ekonomi global dan semakin pesatnya penggunaan teknologi, menjadikan semakin meningkatnya tuntutan sekolah-sekolah untuk lebih kreatif, inovatif dan responsif. Hal ini biasanya diikuti dengan peningkatan SDM nya;

(2) komposisi dari populasi peserta didik yang berubah. Komposisi peserta didik di kebanyakan sekolah saat ini secara radikal berbeda dan lebih menantang untuk para pendidik dari pada masa lalu;

(3) kritik dari masyarakat yang dirasakan kurang mendukung (Henderson \& Milstein, 2003).

Sekolah sebagai lingkungan kritis memang sangat strategis untuk membangun resiliensi siswa. Menurut Benard (1991) kondisi lingkungan yang perlu diperhatikan pendidik dalam membangun resiliensi siswa, yaitu provide caring and support (memberikan perhatian \& dukungan), set and communicate high expectations (menetapkan \& mengkomunikasikan harapanharapan yang tinggi tapi realistik, sehingga dapat menjadi motivator yang efektif), dan provide opportunities for meaningful participation (memberikan kesempatan untuk patisipasi yang bermakna).

Sebagai seorang pendidik, guru yang efektif, tidak hanya efektif dalam kegiatan pembelajaran di kelas saja (transfer of knowledge), tetapi lebihlebih dalam relasi pribadinya dan "modeling" nya (transfer of attitude and values), baik kepada peserta didik maupun kepada seluruh anggota komunitas sekolah. Kemampuan pendidik menghadirkan diri sedemikian rupa sehingga memiliki relasi yang bermakna pendidikan dengan para peserta didik sangat diperlukan. Relasi yang bermakna akan mudah terwujud jika terjadi komunikasi yang efektif, yaitu saling menghormati, menghargai dan menerima. Dalam suasana relasi dan komunikasi yang efektif peserta didik akan lebih mudah mengeksplorasi dan mengembangkan dirinya sehingga mereka mampu menumbuhkembangkan dirinya menjadi pribadi dewasa dan matang. Dengan demikian, sangatlah disadari bahwa kualitas kepribadian pendidik, kedewasaan, kematangan perasaan, efektivitas dan integritas pribadi akan mempunyai peran besar dalam proses pendidikan (Riyanto, 
2004). Terkait dengan hal tersebut,penelitian ini bertujuan untuk memperoleh gambaran umum profile resiliensi pendidik Fakultas Psikologi Unair melalui Resilience Quotient Test (RQ)

\section{Metode Penelitian}

Penelitian ini merupakan penelitian deskriptif yang hanya melibatkan satu variabel mandiri, yaitu resiliensi. Hasil penelitian dilaporkan dalam bentuk profile. Analisis profile dilakukan berdasarkan perbandingan nilai rata-rata dari masing-masing faktor resiliensi dengan nilai acuan yang sudah ditentukan dalam Resilience Quotient Test. Instrumen pengukuran resiliensi menggunakan Resilience Quotient Test yang mencakup 7 kemampuan, yaitu: regulasi emosi, kontrol impuls, empati, optimisme, analisis kausal, selfefficacy, dan reaching out. Ketujuh kemampuan tersebut disebut sebagai 7 faktor resiliensi (Reivich K and Shatte A., 1999). Berikut adalah pemaparan masing-masing faktor yang tercakup dalam resiliensi:

\section{Regulasi Emosi (Emotional Regulation)}

Regulasi emosi merupakan kemampuan untuk tetap tenang dalam kondisi yang penuh tekanan. Individu yang resilien menggunakan serangkaian ketrampilan yang telah dikembangkan untuk membantu mengontrol emosi, atensi dan perilakunya. Kemampuan regulasi penting untuk menjalin hubungan interpersonal, kesuksesan kerja dan mempertahankan kesehatan fisik. Tidak setiap emosi harus diperbaiki atau dikontrol. Ekspresi emosi secara tepatlah yang menjadi bagian dari resiliensi.

\section{Kontrol Impuls (Impulse Control)}

Kontrol impuls berkaitan erat dengan kemampuan regulasi emosi. Individu dengan kontrol impuls yang kuat, cenderung memiliki regulasi emosi yang tinggi, sedangkan individu dengan kontrol emosi yang rendah cenderung menerima keyakinan secara impulsif, yaitu suatu situasi sebagai kebenaran dan bertindak atas dasar hal tersebut. Kondisi ini seringkali menimbulkan konsekuensi negatif yang dapat menghambat resiliensi. 


\section{Optimisme (Optimism)}

Individu yang resilien adalah individu yang optimis. Mereka yakin bahwa berbagai hal dapat berubah menjadi lebih baik. Mereka memiliki harapan terhadap masa depan \& percaya bahwa mereka dapat mengontrol arah kehidupannya. Dibandingkan orang yang pesimis, individu yang optimis lebih sehat secara fisik, cenderung tidak mengalami depresi, berprestasi lebih baik di sekolah, lebih produktif dalam bekerja dan lebih berprestasi dalam olah raga.

\section{Analisis Kausal (Causal Analysis)}

Analisis kausal merupakan istilah yang digunakan untuk merujuk pada kemampuan individu untuk secara akurat mengidentifikasi penyebabpenyebab dari permasalahan mereka. Jika seseorang tidak mampu memperkirakan penyebab dari permasalahannya secara akurat, maka individu tersebut akan membuat kesalahan yang sama.

\section{Empati (Empathy)}

Empati menggambarkan sebaik apa seseorang dapat membaca petunjuk dari orang lain berkaitan dengan kondisi psikologis dan emosional orang tersebut. Beberapa individu dapat menginterpretasikan perilaku nonverbal orang lain, seperti ekspresi wajah, nada suara dan bahasa tubuh serta menentukan apa yang dipikirkan dan dirisaukan orang tersebut. Ketidakmampuan dalam hal ini akan berdampak pada kesuksesan dan menunjukkan perilaku nonresilien.

\section{Self-Efficacy}

Self-efficacy menggambarkan keyakinan seseorang bahwa ia dapat memecahkan masalah yang dialaminya dan keyakinan seseorang terhadap kemampuannya untuk mencapai kesuksesan. Dalam lingkungan kerja, seseorang yang memiliki keyakinan terhadap dirinya untuk memecahkan masalah muncul sebagai pemimpin.

\section{Reaching Out}

Reaching out menggambarkan kemampuan seseorang untuk mencapai keberhasilan. Resiliensi merupakan sumber untuk mencapai reaching out, 
karena resiliensi memungkinkan kita untuk meningkatkan aspek-aspek positif dalam kehidupan.

Berikut ini disajikan pengelompokan item-item Resilience Quotient Test berdasarkan faktor-faktor.

Tabel 1. Pengelompokan item-item Resilience Quotient Test

\begin{tabular}{llll}
\hline \multicolumn{1}{c}{ Faktor } & \multicolumn{1}{c}{ Favourable } & \multicolumn{1}{c}{ Unfavourable } \\
\hline 1. & Emotion Regulation & $13,25,26,56$ & $2,7,23,31$ \\
2. & Impulse Control & $4,15,42,47$ & $11,35,38,55$ \\
3. & Empathy & $10,34,37,46$ & $24,30,50,54$ \\
4. & Optimism & $18,27,32,53$ & $3,33,39,43$ \\
5. & Causal Analysis & $12,19,21,48$ & $1,41,44,52$ \\
6. & Self-Efficacy & $5,28,29,49$ & $9,17,20,22$ \\
7. & Reaching Out & $6,4,14,40$ & $16,35,45,51$ \\
\hline
\end{tabular}

\section{Hasil Penelitian dan Pembahasan}

Hasil analisis data dengan menggunakan teknik statistik deskriptif dalam program SPSS for Windows dapat dilaporkan pada Tabel 2 berikut ini:

Tabel 2. Hasil Resilience Quotient Test (RQ) Staf Pengajar

Fakultas Psikologi Unair

Statistics

\begin{tabular}{lccccccc}
\hline & $\begin{array}{c}\text { Emotional } \\
\text { Regulation }\end{array}$ & $\begin{array}{c}\text { Impulse } \\
\text { Control }\end{array}$ & Empathi & Optimism & $\begin{array}{c}\text { Causal } \\
\text { Analysis }\end{array}$ & $\begin{array}{c}\text { Self- } \\
\text { Efficacy }\end{array}$ & $\begin{array}{c}\text { Reaching- } \\
\text { Out }\end{array}$ \\
\hline N Valid & 17 & 17 & 17 & 17 & 17 & 17 & 17 \\
$\quad$ Missing & 0 & 0 & 0 & 0 & 0 & 0 & 0 \\
Mean & 4.24 & 4.94 & 5.94 & 6.71 & 2.59 & 4.18 & 4.41 \\
Std. Deviation & 2.796 & 4.038 & 4.892 & 2.801 & 3.144 & 2.404 & 3.709 \\
Minimum & -1 & -5 & -5 & 1 & -4 & 0 & -1 \\
Maximum & 8 & 11 & 16 & 12 & 7 & 9 & 10 \\
\hline
\end{tabular}


Nilai rata-rata (mean) dari masing-masing faktor resiliensi di atas akan diinterpretasikan berdasarkan nilai acuan yang sudah ditentukan dalam Resilience Quotient Test. Nilai acuan tersebut dapat dilihat pada Tabel 3 berikut.

Tabel 3. Nilai Acuan 7 Faktor Resilience Quotient Test

\begin{tabular}{cccccccc}
\hline Acuan & $\begin{array}{c}\text { Emotional } \\
\text { Regulation }\end{array}$ & $\begin{array}{c}\text { Impulse } \\
\text { Control }\end{array}$ & Empathi & Optimism & $\begin{array}{c}\text { Causal } \\
\text { Analysis }\end{array}$ & $\begin{array}{c}\text { Self- } \\
\text { Efficacy }\end{array}$ & $\begin{array}{c}\text { Reaching } \\
- \text { Out }\end{array}$ \\
\hline $\begin{array}{c}\text { Above } \\
\text { average }\end{array}$ & $>13$ & $>0$ & $>12$ & $>6$ & $>8$ & $>10$ & $>9$ \\
$\begin{array}{c}\text { Average } \\
\text { Below }\end{array}$ & $6 \mathrm{~s} / \mathrm{d} 13$ & $-6 \mathrm{~s} / \mathrm{d} 0$ & $3 \mathrm{~s} / \mathrm{d} 12$ & $-2 \mathrm{~s} / \mathrm{d} 6$ & $0 \mathrm{~s} / \mathrm{d} 8$ & $6 \mathrm{~s} / \mathrm{d} 10$ & $4 \mathrm{~s} / \mathrm{d} 9$ \\
Average & $<6$ & $<-6$ & $<3$ & $<-2$ & $<0$ & $<6$ & $<4$ \\
\hline
\end{tabular}

Reivich K and Shatte A. (1999). The Resilience Factor.

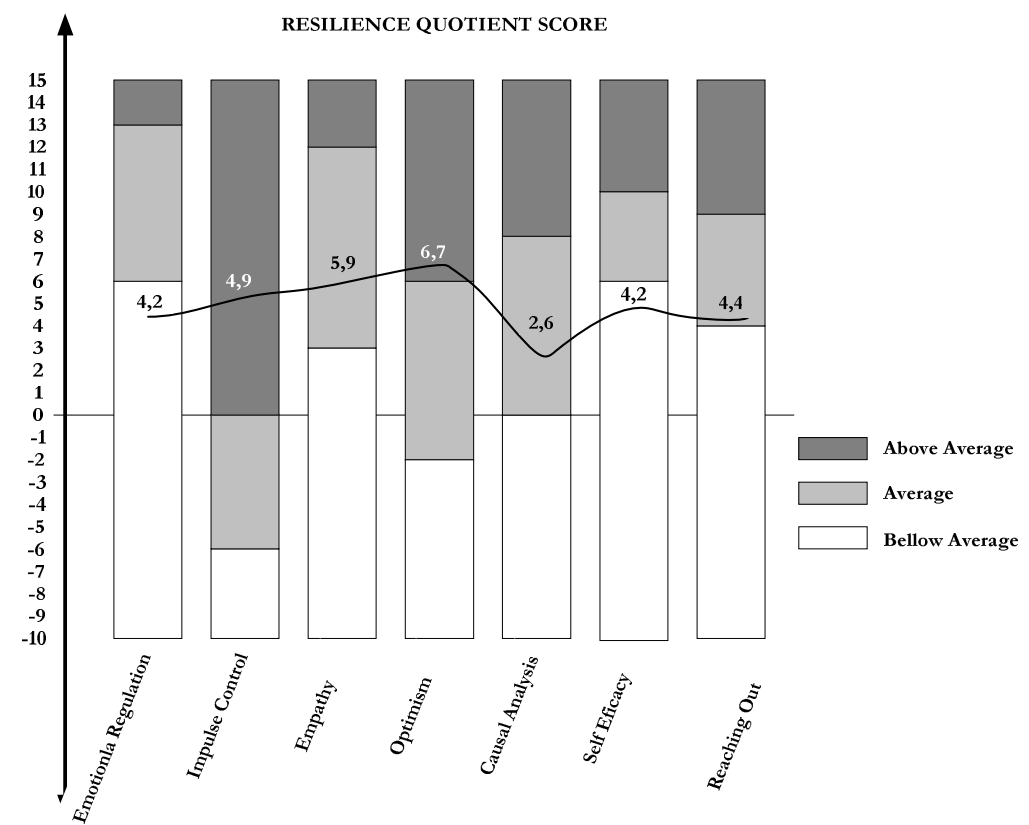

Gambar 3. Profil Resiliensi Quotient Staf Pengajar Fakultas Psikologi Universitas Airlangga 
Perbandingan hasil nilai rata-rata yang diperoleh dengan nilai acuan dari masing-masing faktor menunjukkan bahwa dari 7 faktor resiliensi, 2 faktor berada pada kategori diatas rata-rata (impulse control dan optimism), 3 faktor berada pada kategori rata-rata (empathy, causal analysis dan reaching out) dan 2 faktor berada pada kategori di bawah rata-rata (emotional regulation dan self-efficacy).

Dua faktor yang berada pada kategori diatas rata-rata adalah Impulse Control $(\mathrm{M}=4.94>0)$ dan Optimism $(\mathrm{M}=6,7>6)$. Hal ini menunjukkan bahwa kontrol impuls para pendidik Fakultas Psikologi Universitas Airlangga cukup kuat. Namun demikian, hasil temuan ini cukup menarik, karena kontrol impuls pada dasarnya berkaitan erat dengan kemampuan regulasi emosi, yaitu kemampuan untuk tetap tenang dalam kondisi yang penuh tekanan. Individu dengan kontrol impuls yang kuat, cenderung memiliki regulasi emosi yang tinggi. Padahal, hasil temuan untuk para pendidik menunjukkan kemampuan Emotional Regulation yang rendah (dibawah ratarata, $M=4,2<6$ ). Dengan dihasilkannya nilai rata-rata regulasi emosi yang rendah, maka perlu adanya upaya untuk meningkatkannya. Ada berbagai teknik untuk meningkatkan regulasi emosi, namun strategi yang paling efektif adalah dengan mengubah cara berpikir/berkeyakinan ketika seseorang mengalami kejadian buruk yang menimbulkan perasaan negatif yang kuat. Individu yang resilien menggunakan serangkaian ketrampilan yang telah dikembangkan untuk membantu mengontrol emosi, atensi dan perilakunya. Tindakan yang dilakukan tidak secara impulsife. Kemampuan regulasi ini penting untuk menjalin hubungan interpersonal dan kesuksesan kerja. Tidak setiap emosi harus dikontrol dan diperbaiki, karena ekspresi emosi secara tepatlah yang menjadi bagian dari resiliensi. Keterkaitan antara kontrol impuls dan regulasi emosi tersebut disebabkan karena kedua kemampuan itu berada dalam systems believe yang sama.

Faktor Optimism menunjukkan hasil cukup kuat, artinya para staf pengajar Fakultas Psikologi Universitas Airlangga merupakan sosok individu-individu yang optimis, mereka melihat masa depan yang cerah dan memiliki harapan terhadap masa depan. Mereka juga yakin bahwa berbagai 
hal dapat berubah menjadi lebih baik. Individu yang optimis akan berprestasi lebih baik \& lebih produktif dalam bekerja. Temuan ini juga cukup menarik, karena faktor Optimism pada dasarnya berkaitan erat dengan faktor Self-Efficacy. Self-efficacy menggambarkan keyakinan seseorang bahwa ia dapat memecahkan masalah yang dialaminya dan keyakinan seseorang terhadap kemampuannya untuk mencapai kesuksesan. Individu yang optimis akan memotivasi dirinya untuk menyelesaikan suatu masalah dan memperbaiki situasi. Padahal, hasil temuan untuk para staf pengajar menunjukkan nilai Self-Efficacy yang rendah (dibawah rata-rata, $\mathrm{M}=4,18<10$ ). Oleh karena itu, temuan hasil faktor resiliensi yang tidak seiring ini perlu juga dikaji lebih lanjut, karena kunci untuk mencapai resiliensi dan kesuksesan adalah pasangan Optimism dan Self-Efficacy.

Untuk ketiga faktor lainnya, yaitu Empathy, Causal Analysis dan Reaching-Out berada dalam kategori rata-rata. Skor empati yang cukup menunjukkan bahwa para staf pengajar cukup mampu membaca kondisi psikologis dan emosional yang ditunjukkan oleh orang lain, mereka cukup mampu merasakan apa yang dipikirkan dan dirisaukan orang lain. Demikian pula keyakinan terhadap kemampuannya untuk mencapai kesuksesan dan kemampuannya untuk melakukan identifikasi terhadap penyebabpenyebab permasalahan yang dihadapi cukup akan menunjang terbentuknya perilaku yang resilien.

\section{Kesimpulan}

1. Gambaran resiliensi staf pengajar Fakultas Psikologi Universitas Airlangga yang diungkap dengan Resilience Quotient Test (RQ) masih perlu dikaji lebih dalam, karena dari tujuh faktor terdapat beberapa faktor yang menunjukkan hasil yang saling berlawanan;

2. Dua faktor yang berada pada kategori di atas rata-rata, yaitu Impulse Control dan Optimism belum menunjukkan hasil yang mantap karena tidak didukung oleh faktor lainnya yang berada dalam system belief yang sama, yaitu Emotional Regulation dan Self-efficacy; 
3. Hasil yang diperoleh dari faktor Impulse Control yang berlawanan dengan Emotional Regulation perlu adanya kajian lebih dalam. Demikian pula untuk faktor Optimism dan Self-efficacy;

4. Upaya untuk meningkatkan Emotional Regulation dan Self-efficacy merupakan program yang perlu dirancangkan sebagai tindak lanjut hasil analisis kebutuhan psikologis, karena Emotional Regulation akan mempunyai peran penting bagi staf pengajar dalam mewujudkan fungsinya sebagai pendidik yang tidak hanya sebagai agent transfer of knowledge tetapi juga transfer of attitude.

\section{Daftar Pustaka}

Anonim. (2010. )The resiliency center. Artikel diunduh dari www.resiliencycenter.com.

Anomim. (2010). What we have learned. Artikel diunduh dari www.wested.org.

Benard, B. (1991). Fostering resiliency in kids. Portland, OR:Western Regional Center for Drug-Free Schools and Communities, Nortwest Regional Educational Laboratory.

Cohn, M.A. (2009). Happines unpacked: Positive emotions increase life satisfaction by building resilience. American Psychological Association.

Frankenburg, W., (1987). Fifth international conference: early identification of children at risk: Resilience factors in prediction. University of Colorado, Denver, CO.

Garmezy, N. (1985). Stress-resistant children: The search for protective factors. In: J.E. Stevenson (Ed.) Recent Research in Developmental Psychopathology, Journal of Child Psychology and Psychiatry Book Supplement No. 4 (213-233). Oxford: Pergamon Press. 
Gordon, E., \& Song, L.D., (1994). Variations in the experience of resilience. In: M. Wang \& E. Gordon (Eds.). Educational resilience in inner-city America, 27-43.

Grotberg, E. H., (1999). Countering deppresion with the five building blocks of resilience. Diakses pada 17 September 2006 dari (http://www.neoonline.com.

Henderson, N., \& Milstein, M.N. (2003). Resiliency in Schools. Corwin Press, Inc.

Jackson, R., Watkin, C. (2004). The Resilience Inventory: Seven Essential Skills for Overcoming Life's Obstacles and Determining Happiness. Selection and Development Review, Vol. 20, No. 6 December 2004.

Klohnen, E.C. (1996). Conseptual analysis and measurement of the construct of ego resilience. Journal of Personality and Social Psychology, Volume. 70 No 5, p 1067-1079.

Krovetz M.L. (1999). Fostering resiliency. Corwin Press, Inc.

Luthar, S.S., Cicchetti, D., Becker, B., (2000). The Construct of Resilience: A Critical Evaluation and Guidelines for Future Work. Child Development; 71 (3): 543-562 http://www.pubmedcentral.nih.gov/articlerender.fcgi?artid $=1885202$.

Reivich, K., \& Shatte, A. (1999). The Resilience Factor: 7 Keys to Finding Your Inner Strength and Overcoming Life's Inevitable Obstacles.

Reivich, K., \& Shatte, A. (2002). The resilience factor: 7 keys to finding your inner strength and overcoming life's hurdles. New York: Broadway Books.

Rutter, M. (1987). Psychosocial resilience and protective mechanisms. American Journal of Orthopsychiatry. 57: 316-33. 
Theo Riyanto. (2004). Pendidikan yang Humanis.http://bruderfic.or.id/h60/pendidikan-yang-humanis.html.

Tugade, M.M., Fredickson, B.L. (2004). Resilient individuals use positive emotions to bounce back from negative emotional experiences. Journal of Personality and Social Psychology, Vol 86, no.2, 320-333.

Werner, E., \& Smith, R.S., (1982). Vulnerable but invincible: A longitudinal study of resilient children and youth. New York: McGraw Hill. 